(case 2 in our publication, whose father was no longer alive for observations) was a case of Mediterraneanhremoglobin $E^{\prime}$ disease. In addition, two other cases of Mediterranean-hæmoglobin $E$ disease were discovered. In those carrying the trait, hrmoglobin $E$ formed the minor component, whereas in Meditorranean-hrmoglobin $E$ disease the pathological hæmoglobin was the major component (judged from the intensity of the spots on the paper). This fact was also observed by Chernoff et al. in their study of hæmoglobin $E$ in Thailand. There was no increase in foetal hæmoglobin (by Singer, Chernoff and Singer's method $^{4}$ ) in any of the carriers of the trait examined.

Lohman (personal communication) recently found two carriers of the hæmoglobin $E$ trait among people from Ceylon.

It is probable that hæmoglobin $E$ is prevalent in South-East Asia, and a study of its incidence in different areas of this part of the world is of anthropological interest.

This work is continuing, and a more complete report will be made in the future.

Drs. Itano, Bergron and Sturgeon, who kindly made a comparative study of my pathological hæmoglobin with their own hæmoglobin $E$, found that the formor is exactly the same as the original hamoglobin $E$ described by them in 1954. Dr. Itano established the identity by moving-boundary electrophoresis both at $p H 6.5$ and 8.6 .

Department of Parasitology and LiE-INJO LuAN ENG General Pathology,

University of Indonesia. March 25.

I Chernoff, A. I., Minnich, V., and Soodsarkorn Chongchareonsuk, Science, 120, 605 (1954). Nanakara, S., Minnich, V., and Chernoff, A. I., Proc. Central Soc. Clin. Res., 27,89 (1954).

${ }^{2}$ Lie-Injo Luan Eng and Jo Kian Tjay, Doc. med. geograph. trop., $\boldsymbol{\gamma}, 30(\mathbf{1 9 5 5 )}$.

${ }^{3}$ Smith, F. W., and Conley, C. L., Bull. Johns Hopkins Hosp., 98, 94 (1953).

4 Singer, K., Chernof, A. I., and Singer, L., Blood, 6, No. 5 (1951).

\section{Predation Pressure and Evolution in Lake Nyasa}

IN papers dealing with the evolution of fishes in the Great Lakes of East and Central Africa, Worthington ${ }^{1-3}$ postulates that a major contributory factor to the great adaptive radiation shown by the family Cichlidae in certain lakes, notably Victoria, Edward and Nyasa, has been the absence from their waters of active predators. The theoretical implications of this suggestion have been accepted by Huxley ${ }^{4}$ but have been eriticized by Mayr ${ }^{5}$.

Worthington's supposition is that large and vigorous predaceous fishes of the genera Lates and Hydrocyon which are present in several African lakes have played an important part in restricting the adaptive radiation of the non-predaceous species. In Lake Nyasa, where these genera are not represented, he claims that their place is taken by a much less vigorous type of predator in the form of two species of Barilius, and as a result large-scale radiation has been perrnitted to occur.

The results of recent work by us on the ecology and feeding habits of fishes inhabiting both the inshore regions and open waters, together with the results of the 1939 fishery surveys ${ }^{6}$ and the work of Low $\theta^{7}$, indicate that the restrictive effects of predation are not so important as Worthington suggests, as it is now clear that Lake Nyasa harbours a large number of markedly predaceous fishes, oach major habitat having its complement of predators. Although a difference in degree of predation exerted by Lates and Hydrocyon and by the Nyasan predators is not denied, this is probably compensated for by the great numerical abundance of some of the Nyasan species.

Predaceous species of the family Cichlidae include the following : Rhamphocromis (at least eight species), the dentition and diet of which are similar to that occupied by the pikes of Europe and North America ; Serranochromis thumbergi (Castelnau), Aristochromis christy $i$ Trewavas, and several species of Haplochromis, for example, $H$. kiwinge Ahl, $H$. dimidiatus (Günther) $H$. compressiceps (Boulenger) and H. macrostoma Regan. The non-cichlid piscivorous species include Bagrus meridionalis Günther, Barilius microcephalus Günther, Barbus rhoadesii Boulenger, and several species of Clarias.

Many of these species feed exolusively or almost exclusively on fishes except, of course, when very young. In addition, many other species living in the Lake can be classed as mild predators which take fish as part of their diet. Further, it has been observed that almost any fish in the Lake, be it carnivore or herbivore, will take the eggs or fry of other fishes whenever the opportunity to do so arises.

Fishes in Lake Nyasa, therefore, do not lead lives which are relatively uninfluenced by predators as Worthington suggests. On the contrary, the percentago of predators appears to be extremely high, and as it is improbable that all the predators represent the most recently evolved species there is no reason to suppose that, except perhaps in the very early stages of colonization, the Lake has ever been without its complement of predaceous species.

The fact that we cannot agree with the suggestion that the great adaptive radiation shown by the Nyasan fish fauna has taken place largely because of the absence of predators does not mean that we adopt Mayr's view that the phenomenon can be explained on the basis of succession of colonizations from a number of different river systems. This, while it may have played some part in the initial stages of the process can certainly be discounted as an important cause of the state of affairs which exists to-day. The purpose of the present note, however, is not to propose new theories but to indicate that a previously widely eirculated view can no longer be held.

G. Fryer

T. D. Ires

Joint Fisheries Research Organization, Nkata Bay, Nyasaland.

${ }^{2}$ Worthington, E. B., Int. Rev. Hydrob., 35, 304 (1937).

2 Worthington, E. B., in “The New Systematics", edit. J. S. Huxley, 287 (London, 1940)

3 Worthington, E. B., Nature, 173, 1064 (1954).

"Huxley, J. S., "Evolution : the Modern Synthesis" (London, 1942).

"Mayr, E., "Systematics and the Origin of Species", 272, 273 (Columbia, 1942).

" Bertram, C. K. R., Borley, H. J. H., and Trewavas, E., "Report on the Fish and Tisheries of Lake Nyasa" (London, 1942).

' Lowe, R. H., "Report on the 'Lilapta and other Fish and Fisherles of Lake Nyasa" (London, 1052).

\section{So-called Endosperm Embryos in Isomeris arborea Nutt}

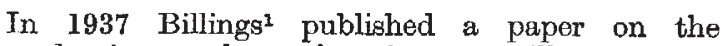
reproductive cytology of angiosperms, illustrated by Isomeris arborea. His observations may be summarized as follows: ( 1 ) this plant is a haploid with a complement of 17 chromosomes; there is no true meiosis or syngamy; (2) the megaspore mother cell 